\title{
The mediating role of self-differentiation in the relationship between resiliency and marital burnout in married women
}

\author{
Salman Zarei ${ }^{1}$ \\ 1-Assistant professor in counseling, Psychology Department, Lorestan University, Khorramabad, Iran \\ (Corresponding Author). ORCID: 0000-0002-4627-4854_E-mail: Salman_zarei@yahoo.com
}

Received: 04/12/2018

Accepted: 23/02/2019

\begin{abstract}
Introduction: The relationship between resiliency and marital burnout has received both theoretical and empirical support. However, less is known about the mechanisms by which resiliency may influence marital burnout.
\end{abstract}

Aim: The aim of present study was to investigate the mediating role of self-differentiation in the relationship between resiliency and marital burnout among married women in Tehran.

Method: The research design was descriptive-correlational, where, 200 participants selected through available sampling. Couple burnout Scale (CBS), Conner and Davidson Resilience Scale (CD-RISC) and Differentiation of Self Inventory (DSI) were coducted to collect data. Then collected data were analyzed using Pearson correlation and path analysis.

Results: Path analysis results showed that resiliency had a significant negative direct effect on marital burnout $(P<0.01, \beta=-0.212)$, whilst it had a significant positive direct effect on self - differentiation ( $\mathrm{P}<0.01, \beta=0.459$ ). Also, Path analysis showed that indirect effect of resiliency on marital burnout through self- differentiation $(\mathrm{P}<0.05, \beta=-0.096)$ was significant.

Conclusion: The present study highlighted the mediating role of self-differentiation as an underlying mechanism between resiliency and marital burnout. Therefore, developing selfdifferentiation in married women could be a good way to protect them in the face of adversities during marital life.

Keywords: Burnout, Differentiation, Marrige, Resiliency

How to cite this article : Zarei S. The mediating role of self-differentiation in the relationship between resiliency and marital burnout in married women. Shenakht Journal of Psychology and Psychiatry. 2019; 6 (2): 62-73 .URL :http://shenakht.muk.ac.ir/article-1-590-fa.pdf

Copyright ( $) 2018$ the Author (s). Published by Kurdistan University of Medical Sciences. This is an open access article distributed under the terms of the Creative Commons Attribution-Non Commercial License 4.0 (CCBY-NC), where it is permissible to download, share, remix, transform, and buildup the work provided it is properly cited. The work cannot be used commercially without permission from the journal. 


\section{نقش واسطه اى خودتمايزيافتكى در رابطه بين تابآورى با دلزدىى زناشويى در زنان متاهل}

سلمان زارعى'

ا.استاديار مشاوره، گروه روان شناسى، دانشگاه لرستان، خرم آباد، ايران (مولف مسئول). ايميل: Salman_zarei@yahoo.com

مقدمه: رابطه بين تاب آورى و فرسودگى زناشويى از حمايت نظرى و تجربى كافى برخوردار است، اما درباره سازو كارهاى كه

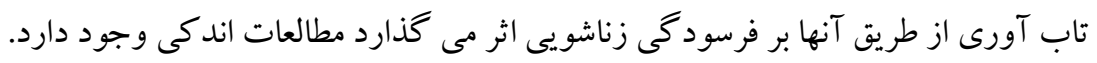

هدف: يثزوهش حاضر با هدف مطالعه نقش واسطه اى خودتمايزيافتكى در رابطه بين تابآورى با دلزدگى زناشويى در بين زنان متاهل شهر تهر ان انجام شد.

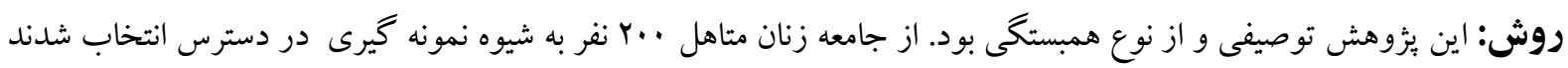

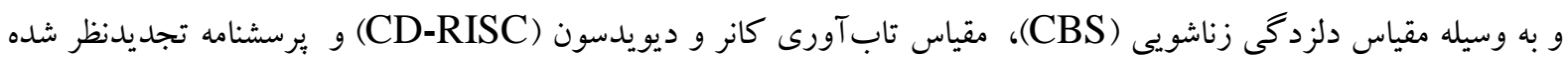

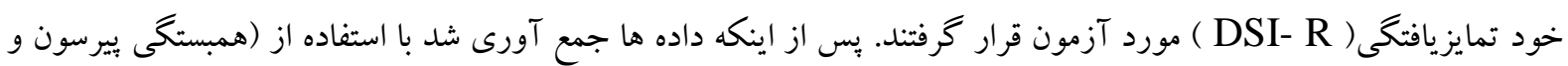
تحليل مسير) تحليل شدند.

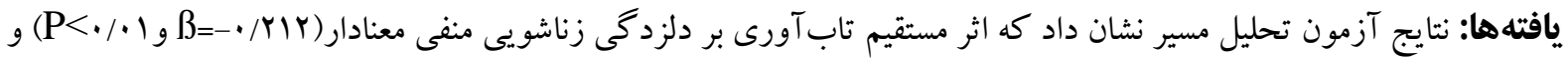

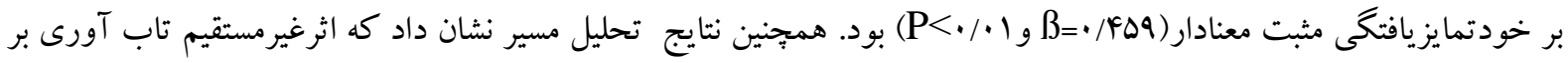

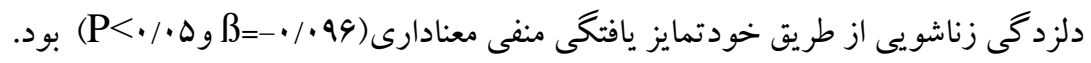
نتيجه كيرى: مطالعه حاضر بر نقش واسطه اى خودتمايزيافتكى به عنوان يكك سازوكار مهم در رابطه بين تابآورى و دلزدگى

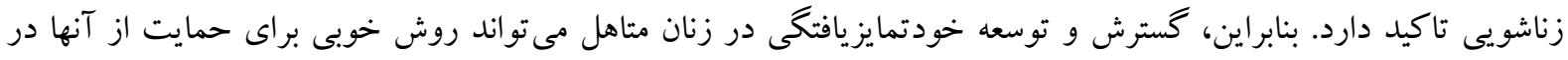
مو اجهه با ناملايمات زندگى زناشويى باشد. كليد وازهها: ازدواج، تاب آورى، دلزدخى خودتمايزيافتخى 


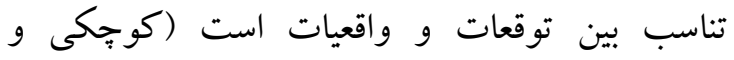

مقدمه

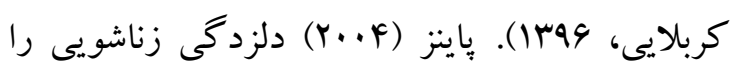
زندكى زناشويى يكى از جهانى ترين نيازهاى بشرى سرخورد گى بيش رونده در نظر مى گيرد كه شامل سه

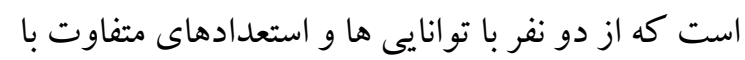

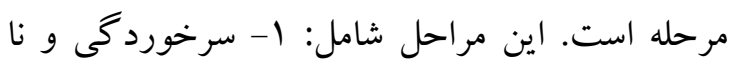
نياز ها و علايق مختلف و در يكك كلام با شخصيت اميدى، r- خشم و تنفر و r- دلسردى و بى تفاوتى است. علاوه بر اين در بزوهشى بار مسئوليت اضافى،

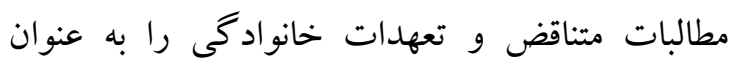
عواملى مشخص كرده است كه بيشترين تاثير را بر دلزدگى زناشويى دارند. در بررسى عوامل درون فردى تاثير گذار بر دلزدگى دونى

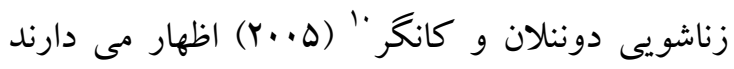
كه تاب آورى " به عنوان يك ويز گكى شخصيتى تاثير

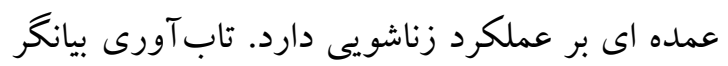

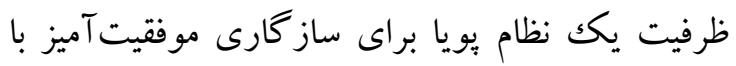
اختلالهايى است كه عملكرد، موجوديت يا فرايند رشد آن نظام را مورد تهديد قرار مىدهد (ماستن" بات،

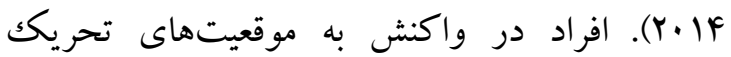
كننده و تعارض آميز با يكديخر متفاوتاند. اكر افراد داراى تابآورى بالا باشند، در شرايط استرسزا و و

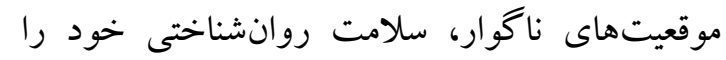
حفظ مى كنند و سازكارى روانشناختى بالايى نشان

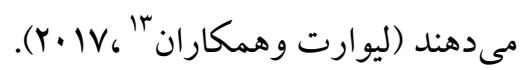

نف و بردلى "(1) باعث مى شود افراد در شرايط دشوار زندگى زناشويى و با وجود عوامل استرسزا، از ظرفيتهاى موجود خود در دست يابى به موفقيت و رشد زندگى فردى و به تبع آن خانوادگى استفاده كنند و از اين خالش ها و آزمون هاى گوناكون تشكيل شده است (كلدنبرگك و و

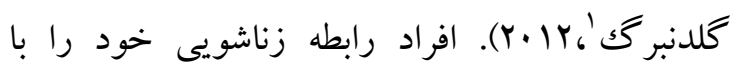
نخرش و احساسهاى مثبت آغاز مى كنند، ولى به تدريج هنگامى درمىيابند رفتار همسرشان آنكونه نيست كه انتظارش را داشتهاند، احساسى هاى منفى در در

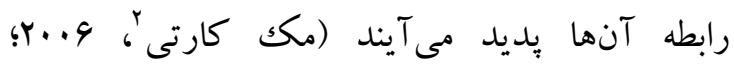

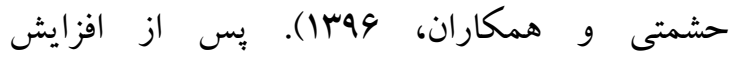
سرخوردگى و تنشهاى برآمده از برآورده نشدن خواستها و نيازهاى ميان فردى، احساس سرخوردئى آشكارا به همسر نسبت داده مىشود و اين مايه از دست رفتن عشق و تعهد شده و دلزدگى جايگزين شور و

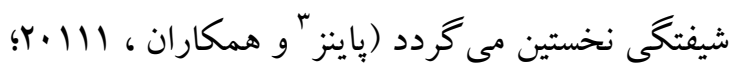

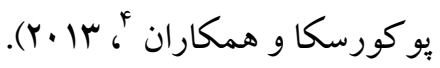

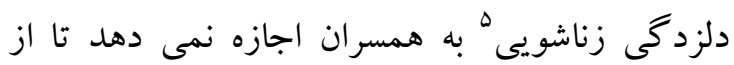

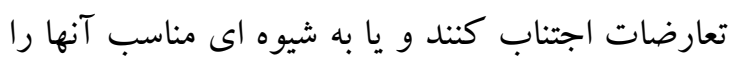
حل كنند، به طورى كه هر دو از ازدواج و رابطه با يكديخر احساس رضايت نمى كنند (جن وَ و همكاران، (Y..VV تدريجى دلبستگى عاطفى است كه كاهش توجه به

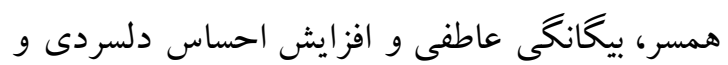

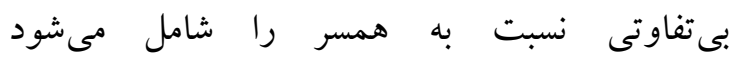

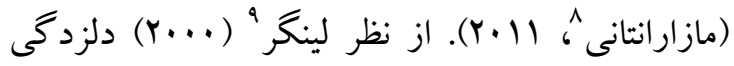
زناشويى، از پا افتادن جسمى و روانى ناشى از عدم ها به عنوان فرصتى براى توانمند كردن خود و ارتقاى

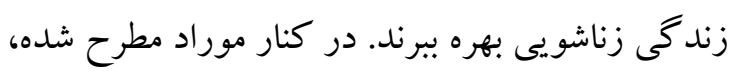

\footnotetext{
${ }^{10}$. Donnellan \& Conger

11 . resiliency

12. Masten

${ }^{13}$. Lievaart

14. Neff \& Bradly
}

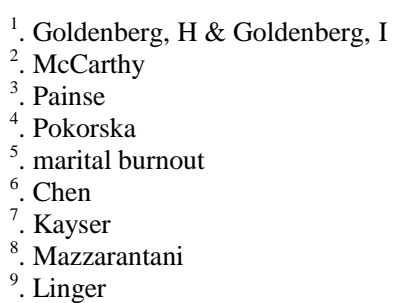


خودتمايزيافتكى نشانگر عملكرد ميان فردى، توانايى جدا كردن فرآيندهاى عاطفى از منطقى و انجام

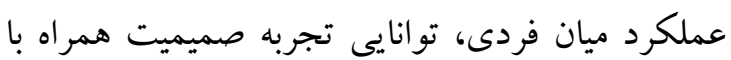

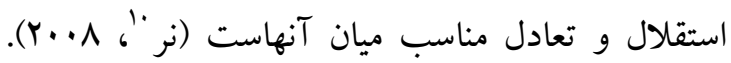
نظريه نظام هاى خانواده عنوان مى كند هر كاه در رابطه زناشويى سطح تمايزيافتكى هر دو زوج يايين باشد هادي آميزش عاطفى بيشترى روى مى دهد كه اين حائ حالت

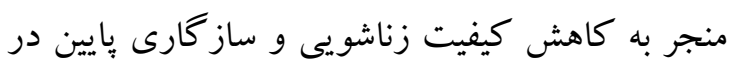

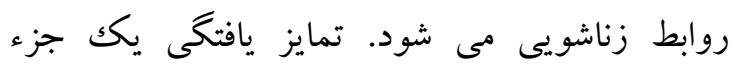

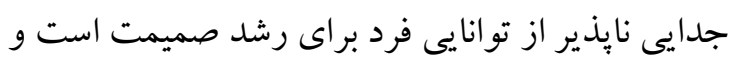

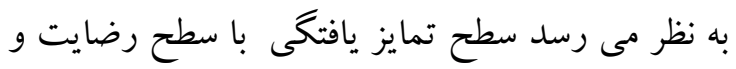

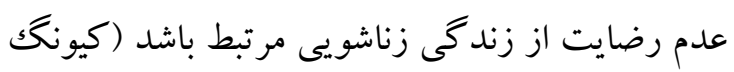

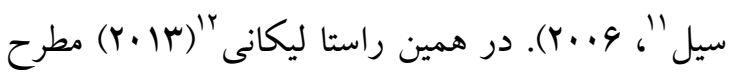
مى كند در نظام زناشويى وقتى تمايزيافتخى زوج ها لهالي

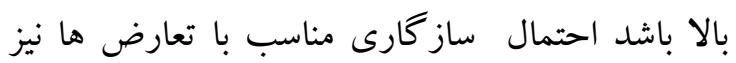
براى زوج ها بيشتر مىشود و اظطراب، واكنش هاى هيجانى و در نهايت آميختخى كاهش مى ميابد، در سمت مقابل، استفاده زوج هاى با تمايز يافتكى بليين از اجتناب به هنگام وقوع تعارض به بر هم زدن تعادل بين

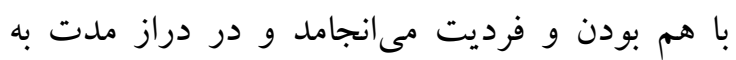

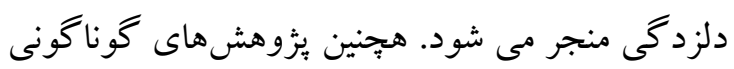

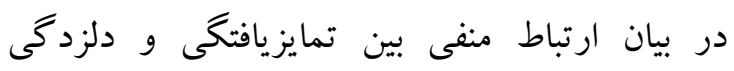
زناشويى نشان داده اند كه هر جه افراد از سطوح تمايز يافتكى هايينترى برخوردار باشند به دليل آميختخى نئى

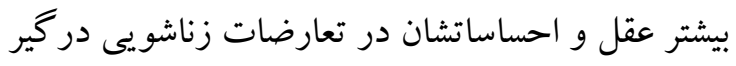
تنشهاى عاطفى شديد با همسر و در طولانى مدت

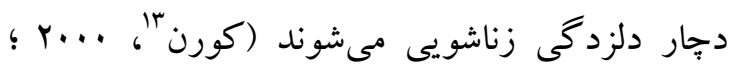

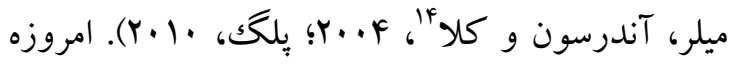
زوجها براى برقراى ارتباط و حفظ رابطه صميمانه

\footnotetext{
10. Knerr

11. Kyung-Sil

${ }^{12}$. Licani

13. Kworn

14. Miller, Anderson \& keala
}

يثزهشها نشان مىدهد كه ويزگ مهمى در رضايت زناشويى، روابط زوجين، كاهش

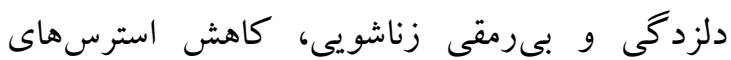
زناشويى و افزايش هيجانات مثبت دارد (هيوبر و

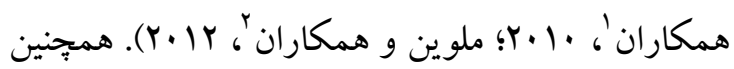

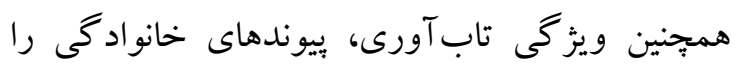
تقويت و باعث ارتقاء مضاعف تاب آورى مىشود. با ارتقاى تاب آورى، فرد مى تواند در برابر عوامل استرس زا، اضطراب آور و همجِنين عو املى كه مسبب به وجود آمدن مشكلات زناشويى و خانود گى مى شود از خود مقاومت نشان داده و بر آنها غلبه كند

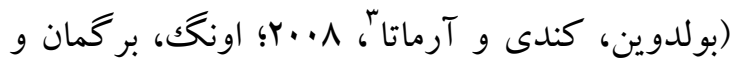

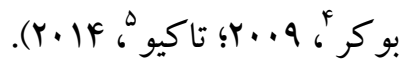

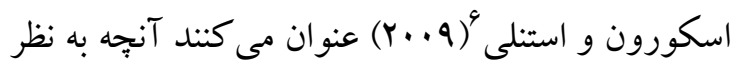
نظر مى رسد در رابطه بين برخى عوامل با هيجانات منفى در زندكى زناشويى نقش مهمى داشته باشد دراند توانايى جدا سازى نسبى اعضاى خانواده و مراقبت از خود در شرايط حساس و هيجان هاى متفاوت است.

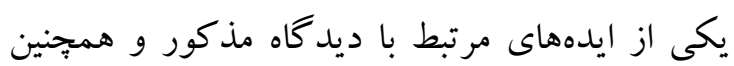
توانايى افراد در تمامى فرهنگك ها براى رسيدن به به به به

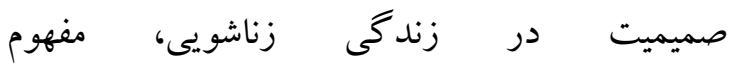

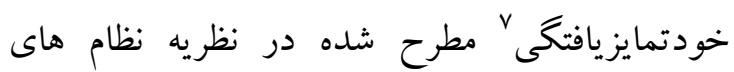

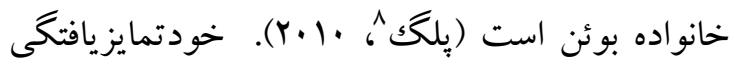
اساس نظريه نظام هاى خانواده است كه به عنوان توانايى فرد براى تجربه صميميت با ديخران و باقى بط بهري ماندن در جو عاطفى خانواده و حفظ استقلال از آنها

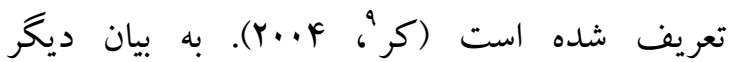

\footnotetext{
1 . Huber

${ }^{2}$. Melvin

3 . Boldwin, Kennedy \& Armata

. Ong, Bergamen \& Boker

5. Taku

6. Skowron \& Stanely

7. self-differentiation

8 . Peleg

9 . Kerr
} 
اكرجه بُزوهش هاى بيشين به بررسى متغيرهاى مورد

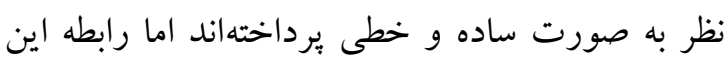
متغيرها به شكل دسته جمعى بررسى نشده است، بنابراين يزوهش حاضر در قالب يكك مدل به دنبال

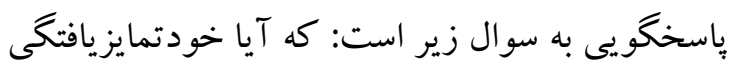
در رابطه بين تابآورى و دلزدگى زناشويى نقش واسطهاى دارد؟ و بر اساس مطالب مطرح شده مدل مفهومى زير مطرح مىشود.
مشكلات شديد و فراگيرى را تجربه مى كنند و در واقع مشكلات زناشويى بيش از هر مقوله ديخر سبب ارجاع و دريافت خدمات روان درمانى و مشاوره خانوادگى است. بر اين اساس مطالعه فرسودگى زناشويى و عوامل دخيل در آن اهميت فراوان دارد. مجموع يثزوهش هاى ذكر شده در مورد تاب آورى، دلزدگى زناشويى و خودتمايزيافتكى اين ايده را مطرح مى كند كه در ارتباط بين تاب اورى و دلزدگى زناشويى، عاملى مانند خودتمايزيافتخى مى تواند نقش واسطهاى داشته باشد.

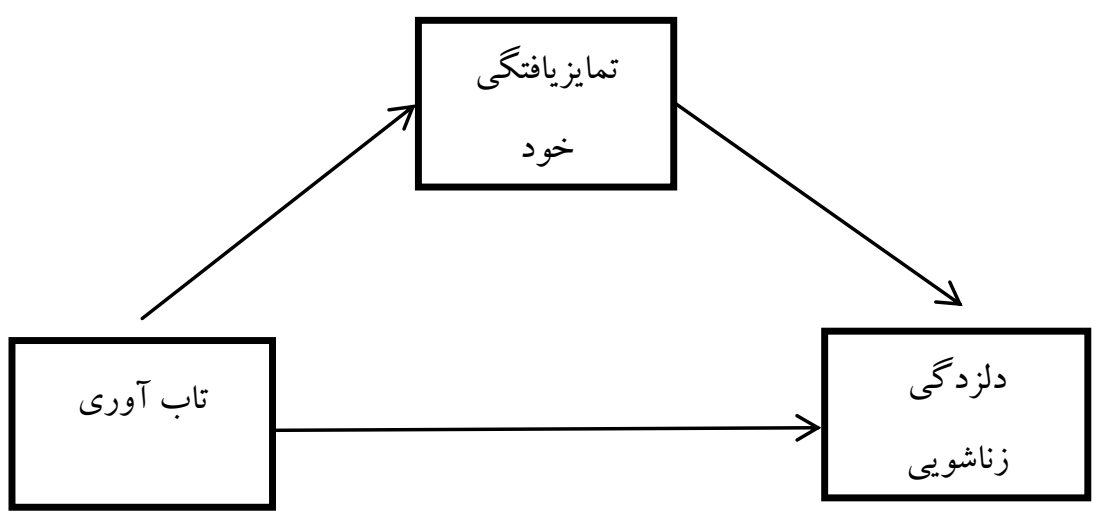

نمودار 1 مدل مفهومى ئووهش

هاى روانشناختى در طول سال كذشته و در حين مطالعه

بود. يُ از مراجعه به خانه هاى سلامت و آشنايى با

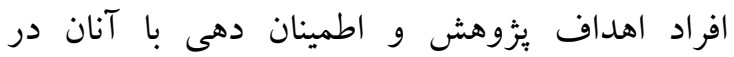
خصوص محرمانه ماندن اطلاعات شخصى يرسش نامه هاى بُزوهش در اختيار آن دسته از زنان متاهلى قرار كرفت كه براى باسخ اعلام آمادكى كردند. همجنين، ملاحضات اخلاقى شامل اخذ رضايت آكاهانه، تضمين حريم خصوصى و رازدارى رعايت گرديد. در نهايت،

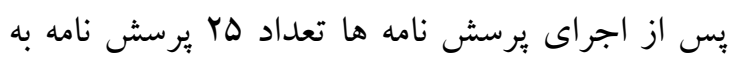
علت مخدوش بودن از روند يُزوهش حذف شد و دادهاى مربوط به . . نفر با استفاده از نسخه V نرم افزار AMOS مورد تحليل قرار گرفت.
يثزوهش حاضر توصيفى و از نوع همبستخى بود. جامعه

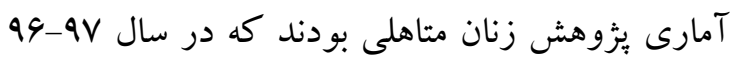
به خانهاى سلامت مناطق ث و ^ شهر تهران مراجعه مى كردند. جهت تعيين حجم نمونه بر اساس ديد كاه كلاين (·. (Y.1) كه عنوان مى كند در مدل هاى تحليل

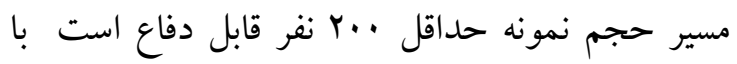
بيش برآورد و با در نظر گرفتن احتمال ريزش نمونه

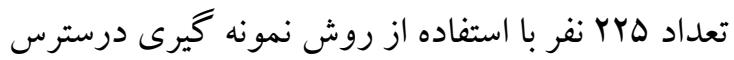
نمونه گيرى در دسترس انتخاب شدند. ملاكك هاى ورود به يُزوهش شامل دامنه سنى •r تا •ه سال، طول مدت ازدواج بيشتر از ه سال و تحصيلات بالاتر از دييلم بود. تنها ملاكك خروج از بثزوهش دريافت درمان 
برعكس. محمدى (IMA9) در يزوهش خود جهت تعيين روايى مقياس از روش تحليل عامل استفاده نمود

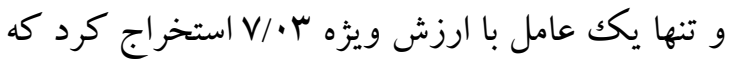

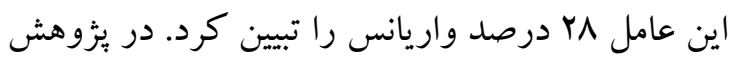

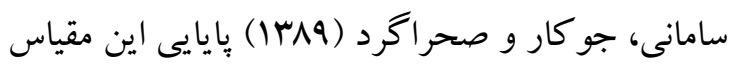

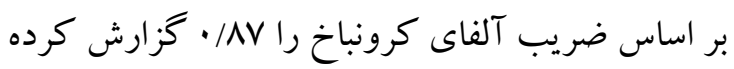
اند. در بثوهش حاضرنيز ضريب آلفاى كرونباخ برابر 119/، بدست آمد كه بيانگر ضريب بايايى مطلوب

\section{مقياس است.}

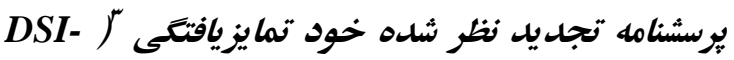

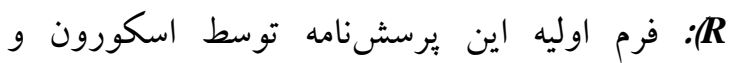
فرايلندر (1991) تهيه شده است و در سال r..r توسط اسكورن و اسميت تجديدنظر شد. نمره گذارى يرسشنامه خود تمايزيافتكى با مقياس ليكرت در يك له طيف و كزينهاى از ا (ابدا در مورد من صحيح نيست) تا 9 (كاملا در مورد من صحيح است) درجهبندى شده است. به هر سوال نمرهاى بين ا و 9 تعلق مى گيرد و و حداكثر نمره اين برسشنامه برابر با rV9 است. نمره كمتر در اين برسشنامه نشانه سطوح بيائين تمايز

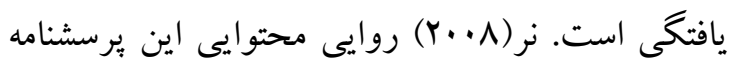

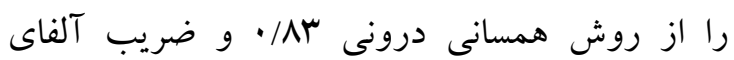

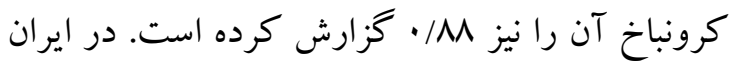

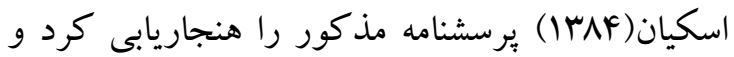
ضريب پايايى براى كل مقياس را بر اساس ضريب

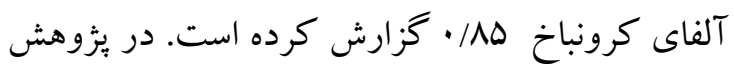
حاضر نيز پِايايى اين ابزار با استفاده از ضريب آلفاى كرونباخ اه/ • محاسبه شد.

\section{يافته ها}

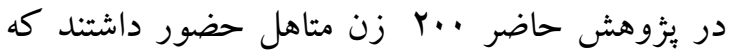
ميانكين و انحراف استاندارد سن آنها به ترتيب برابر با

\footnotetext{
${ }^{3}$. Defferentiation Of Self Inventory Revised
}

ابزار مقياس دلزدكى زناشويیى(CBS): يكك ابزار خودسنجى ال سوالى است كه باينز در سال 1999 ساخته شده است. نمره گذارى اين برسشن بـامه بر اساس

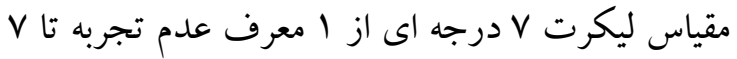
تجربه زياد انجام مىشود كه حد بالاى نمره IFV و حد وِايين نمره Yl است و نمرات بالاتر نشان دهنده فرسودگى بيشتر است. روايى برسش نامه به وسيله بررسى همبستخى هاى منفى با ويز گیىهاى ارتباط مثبت شامل امنيت، خودشكوفايى، احساس هدفمندى به تاييد رسيده است و نسخههاى ترجمه شده به طور

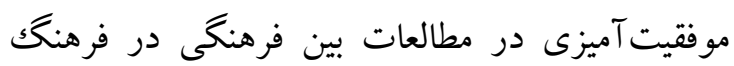
هاى مختلف استفاده شده است. ضريب بايايى اين مقياس با روش بازآزمايى 91// براى يك دوره يك هـ

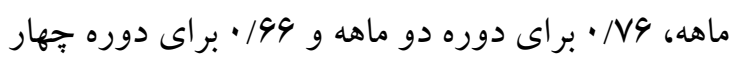
ماهه محاسبه شد. همجنين پيايايى اين مقياس با استفاده از ضريب آلفاى كرونباخ در دامنه بين 191 • تا سو/.

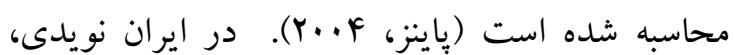

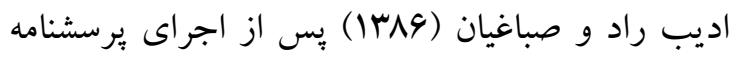

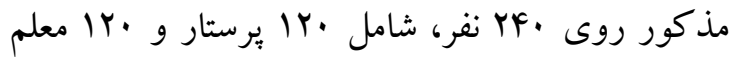
ضريب پيايايى با استفاده از ضريب آلفاى كرونباخ را ران

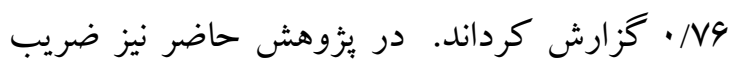
آلفاى كرونباخ برابر با MA/ • به دست آمد. مقياس تابآورى كانو و ديويدسون"( CD-RISC):

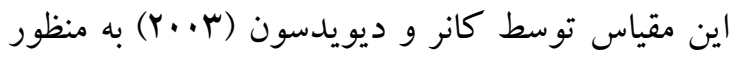
اندازه گيرى مقابله با فشار وتهديد تهيه شده است.

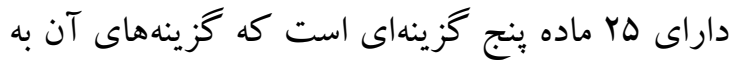

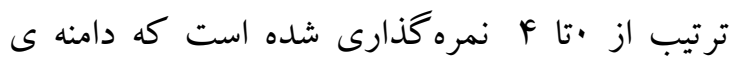
نمرات از · تا ·. 1است و هر جه اين امتياز بالاتر باشد،

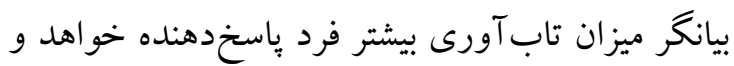

\footnotetext{
1. Couple Burnout Scale

2. Conner \& Davidson Resilience Scale
} 
فوق دييلم، 91 نفر كارشناسى و 1ل نفر نيز كارشناسى ارشد بود. نتايج شاخصهاى توصيفى متغيرهاى ئزوهش در جدول شماره الرايه شده است.

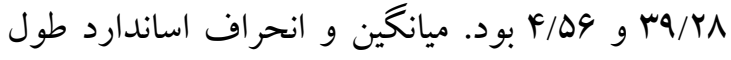

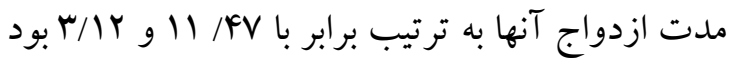
و در اين بين ميزان تحصيلات وه نفر دييلم، بم نفر

\begin{tabular}{|c|c|c|c|c|c|c|}
\hline كشيدكى & كجى & حداكثر نمره & حداقل نمره & انحر اف معيار & ميانكين & متغيرها \\
\hline-.1910 & $-\cdot / Y I F$ & 99 & rı & $\mid r / \Delta r$. & 9N/D. & تاب آورى \\
\hline$-\cdot / V+1$ & $\cdot /$ /Ar & $r$ r. & 149 & $r / N I V$ & $|N| / Y r$ & خودتمايز يافتكى \\
\hline$-\cdot / 4 \pi I$ & $-\cdot / \cdot M$ & 119 & rq & $14 / 991$ & $V \Delta / T r$ & دلزدمى زناشويى \\
\hline
\end{tabular}

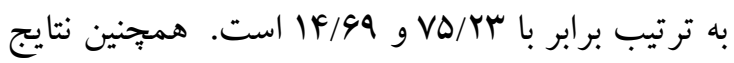
جدول انشان مىدهد كه كجى توزيع نمرهها در دامنه (Y و - Y و كشييد نشانگر نرمال بودن توزيع دادهها است.
يافتهاى جدول ا نشان مى دهد كه ميانگين و انحراف

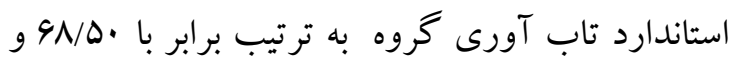

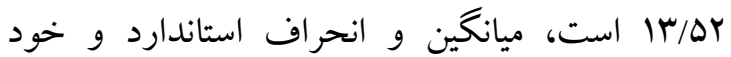
تمايزيافتخى گروه به ترتيب برابر با ساب/M

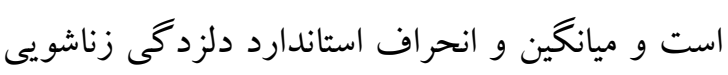

جدول r ضرايب همبتتى تاب آورى و خودتمايز يافتكى و دلزدمىزناشويى

\begin{tabular}{|c|c|c|c|}
\hline$r$ & $r$ & 1 & متغير ها \\
\hline & & 1 & 1 - تابآورى \\
\hline & 1 & $\cdot / k \mid r^{*}$ & r - خودتمايز يافتكى \\
\hline 1 & $-\cdot / r \cdot 4^{*}$ & $-\cdot / r \cdot v^{*}$ & r- دلزدكى زناشويى \\
\hline
\end{tabular}

حجم نمونه و همخطى جند كانه) اطمينان حاصل شود. بهنجارى توزيع دادهها در مراحل قبلى بر اساس كجى و كشيدگى مورد بررسى قرار گرفت. براى حجم نمونه

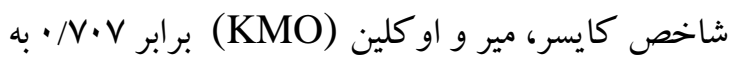
دست آمد كه بيانگر كفايت حجم اين نمونه است (ضريب 9/· به عنوان حداقل مقدار لازم براى تحليل در نظر گرفته مىشود). همخطى جند كانه بين متغيرهاى

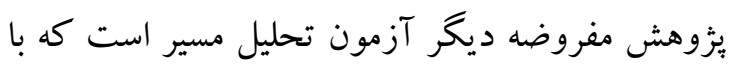
استفاده از آماره تحمل و و عامل تورم واريانس مورد بررسى قرار گرفت و نتايج حاصل نشان مىدهد براى

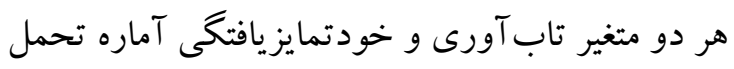

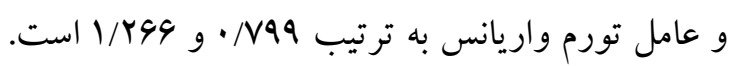

نتايج حاصل از آزمون همبستگى بيرسون در جدول r r

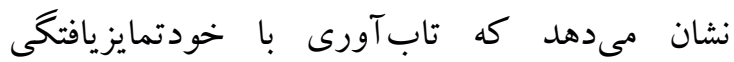

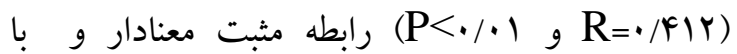
دلزدگى زناشويى (V) منفى معنا دار دارد. افزون بر آن بين خودتمايزيافتكى و ونى

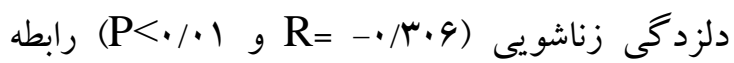
منفى معنادار وجود دارد. وجود همبستگى بين متغيرها دلالت بر انتخاب درست متغيرها در مدل مفهومى دارد.

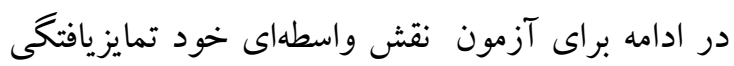
در رابطه بين تابآورى با دلزدگى زناشويى از تحليل مسير استفاده شد. ييش از اجراى اين آزمون بايد از باز برقرارى مفروضههايى اساسى آن (بهنجارى توزيع دادهها، 
برقرارى مفروضههاى آزمون تحليل مسير امكان اجراى اين آزمون فراهم است. در ادمه نتايج تحليل مسير ارايه

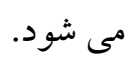

دامنه يذيرش آماره تحمل بزر گتر از • ا/• و عامل تورم واريانس كمتر از •ا است، بنابراين بين متغيرهاى ثُؤهش همخطى جندكانه وجود ندارد. با تاييد
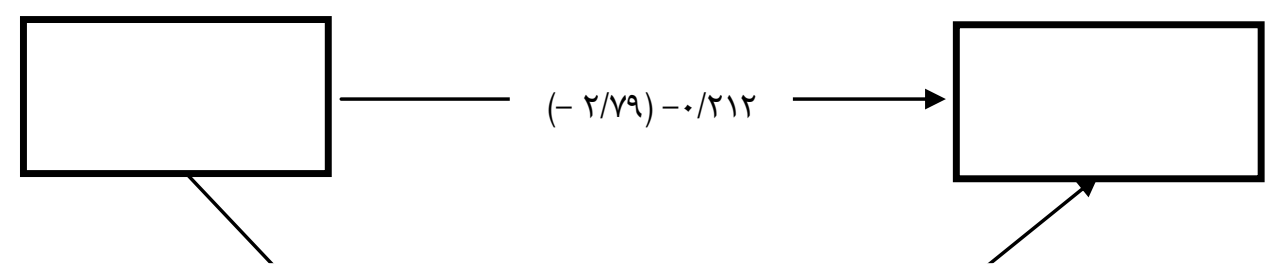

$(V / \backslash Q) \cdot / ז \Delta Q$ $(-r / V Q)-\cdot / 4 \cdot q$

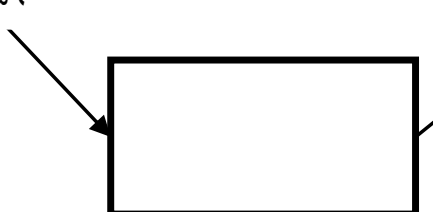

شكل ا مدل مسيرهاى برازش يافته با ضرايب استاندارد و (ضرايب t)

\begin{tabular}{|c|c|c|c|c|c|}
\hline RMSA & يزورهس & A بِيشنهاد & ازندكى & ساحص & ج \\
\hline$\cdot / \cdot V r$ &.$/ . \Delta 1$ & . /qFF &.$/ 94 \mathrm{~V}$ & $\cdot|Q Y|$ & r/DG \\
\hline
\end{tabular}

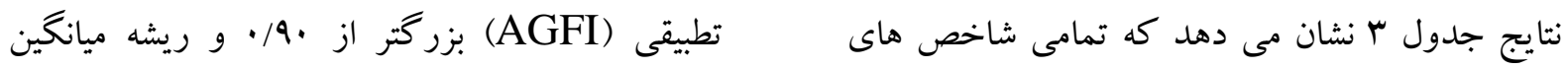

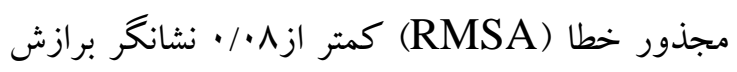
برازش به دست آمده از مطلوبيت بالايى برخوردارند،

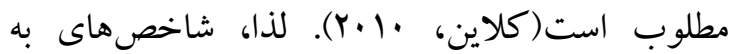

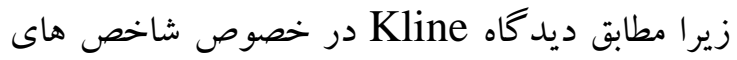
دست آمده نشان مىدهند كه داده ها با مدل مدنظر

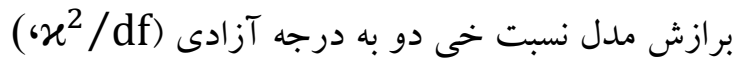
براى روابط متغيرهاى بُروهش برازش دارد. كمتر ازب، شاخص برازش تطيقى (CFI)، شاخص ندان

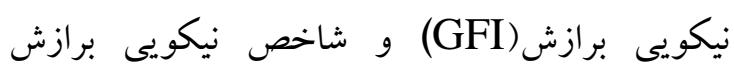

\begin{tabular}{|c|c|c|c|c|}
\hline واريانس تبيين شده & اثر كل & اثر غير مستقيم & اثر مستقيم & مسير ها \\
\hline.$|Y|$ & & & & بر خو دتمايز يافتكى از \\
\hline & $\cdot / F \Delta Q$ & & $\cdot / 4 \Delta Q$ & ت ت تابآورى \\
\hline$\cdot / r q V$ & & & & بر دلزدگى زناشويى از \\
\hline & $-\cdot / r \cdot V$ & -.1 .99 & $-\cdot / r I r$ & تابآورى \\
\hline & $-\cdot / r \cdot q$ & & $-\cdot / r \cdot 9$ & خو دتمايز يافتكى \\
\hline
\end{tabular}


خانودگى نمى كنند از كيفيت زناشويى بالاترى نيز برخوردار هستندو به تبع آن كمتر دجار دلزدگى لنى زناشويى مىشوند. در تبيين اين يافته مىتوان بيان

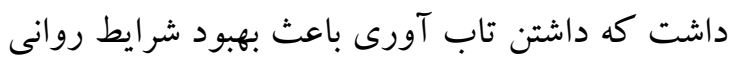
افراد در شرايط تنش زا مى شود. در واقع، تاب آورى به عنو ان نوعى فر آيند يا توانايى به فرد امكان ترسيم و

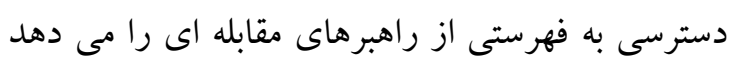

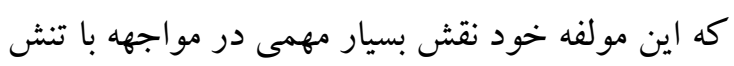
هاى ناشى از جالش هاى زناشويى ايفا مى كند و به

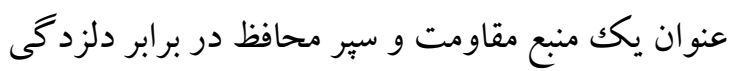

و بر رمقى زناشويى عمل مى نمايد (والش، سا •Y).

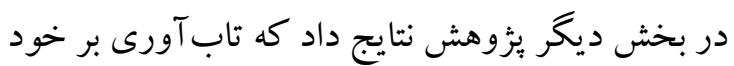

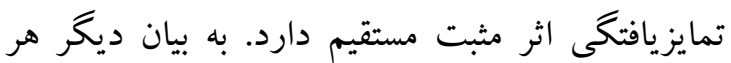
اندازه تابآورى افزايش يابد به همان اندازه خود

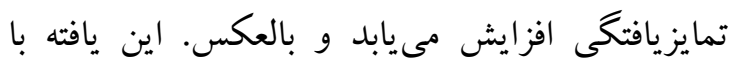

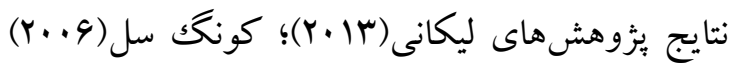
و كورن(Y...

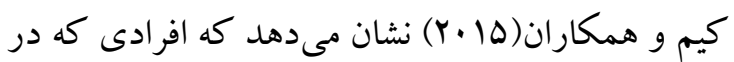
مسائل خانوادكى خود تاب آورى هارئ بالايى دارند از درجه تمايزيافتخى بالايى برخوردار هستد. در تبيين اين يافته مى توان بيان داشت از آنجايى كه هر دو متغير تاب آورى و خودتمايزيافتكى با اضطراب لوابئ رابطه

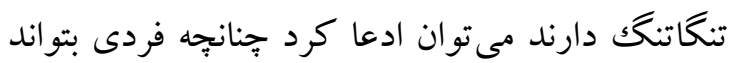
در شرايط اضطرابزا خود را مديريت كند و توانايى تحمل شرايط تنش زا را دشاته باشد از سطح بالايى از تاب اورى برخوردار است و مى توان استدلال كرد كه به احتمال قوى خودتمايزيافتكى بالايى نيز خواهد برد

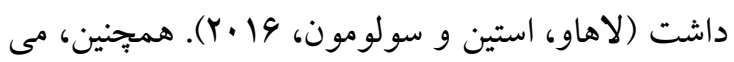

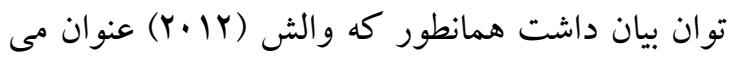
كند كاهش تاب آورى با نوعى احساس فشار روانى و درگيرى شديد عاطفى در روابط بين فردى همر اه است

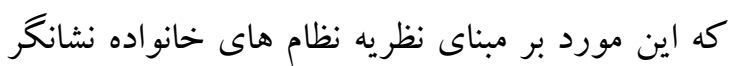

براساس مسيرهاى آزمون شده در جدول F و ساختار

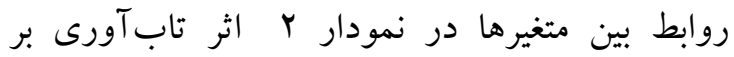

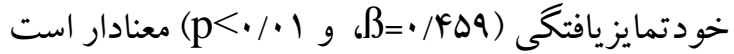
و اين متغير ال درصد از واريانس خودتمايز يافتكى را تبيين مى كند. همجينين، نتايج تحليل مسير نشان داد كه اثر مستقيم (Y)/Y / ( و $\beta=-\cdot / \mu \cdot v)(p<\cdot / \cdot \Delta, \beta=-\cdot / .94)$ تاب آورى بر دلزدگى زناشويى و همبحنين نتايج اثر مستقيم خودتمايزيافتكى بر دلزدگى زناشويى لونى

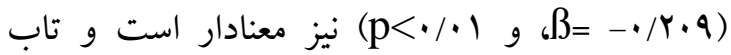
آورى با نقش واسطه اى خودتمايزيافتخى با هم توانايى

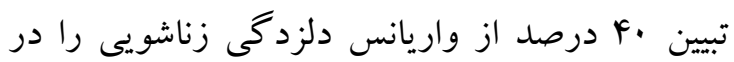

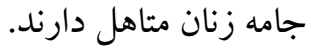

يثزوهش حاضر با هدف بررسى نقش واسطه اى

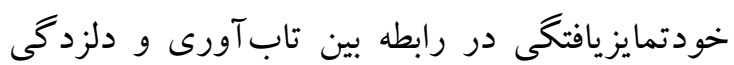
زناشويى در بين زنان متاهل شهر تهران انجام شد. نتايج يثزوهش نشان داد كه تاب آورى بر دلزدگى زناشويى اثر منفى مستقم دارد. اين يافته با نتايج هاى يثوهش حشمتى، قراده، جعفرى و قليزاده (94) (1)، دونانلن و

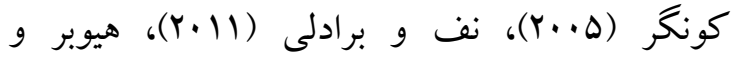

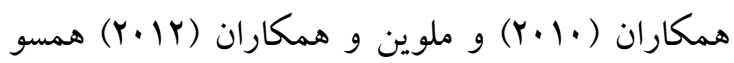
است. همجنين، نتايج يزوهش شجاعى، شجاعى،

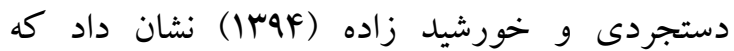
يرستاران زن متاهل كه سطح تاب آورى بالاترى در مقايسه با سايرن دارند، كمتر احتمال دارد در شرايط دشوار زندگى دهار تعارضات و و نارضايتىهاى زناشويى شوند. در كنار موارد ذكر شده نتايج بزوهش

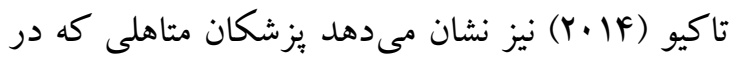
برابر ناملايمات و استرس هاى شغلى خود تاب آورى بالاى دارند و مسايل كارى خود را وارد بافت 
دلزدگى زناشويى نمىشوند جرا كه بهترين راه حل را

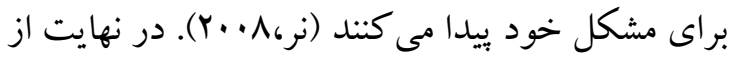
محدوديتهاى بيزوهش حاضر اين است كه تنها بر روى جامعه زنان متاهل شهر تهران اجرا گرديده و و

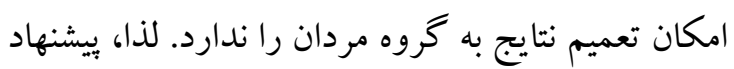
مىشود ئزوهش حاضر در نمونه هاى وسيع تر با فرهنگ هاى متفاوت و در مناطق جغر افيايى ديخر و ورد همجنين در بين مردان نيز انجام شود. همجنين اين

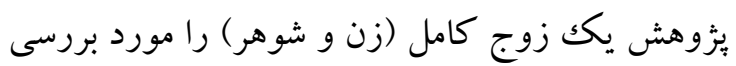

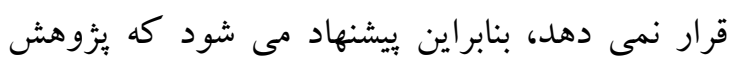

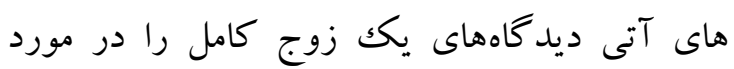
دلزدگى زناشويى، تابـ آورى و خودتمايزيافتكى مورد

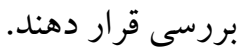

\section{نتيجه كيرى}

مطالعه حاضر بر نقش واسطه اى خودتمايزيافتكى به عنوان يكك مكانيسم مهم در رابطه بين تابآورى و دلزدكى زناشويى در بين زنان متاهل تاكيد دارد. بنابراين، گسترش و توسعه خودتمايزيافتكى در زنان متاهل مىتواند روش خوبى براى حمايت از آنها در

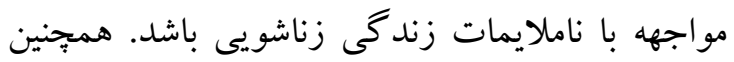

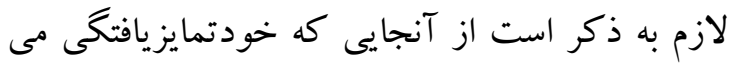
تواند از طريق آموزش و تمرين بهبود يابد مفيد است كه در برنامه هاى بيشخيرى و مداخله اى مورد استفاده

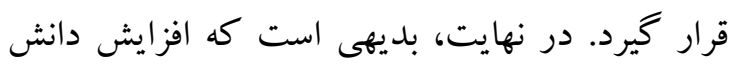
درباره عوامل موثر بر دلزدگى زناشويى و همبحنين

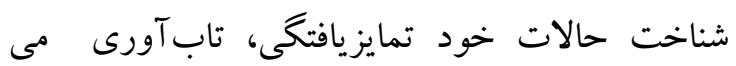
تواند براى خدماتى كه در مشاوره ازدواج و خانواده درمانى طراحى و فراهم مىشود، همواره مفيد و موثر باشد، بنابراين به متخصصين بالينى و مشاوره ويشنهاد

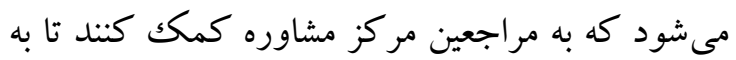

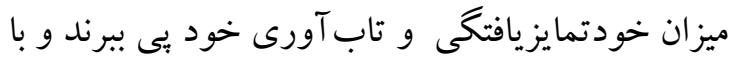

افرادى است كه سطح تمايز يافتكى پايين دارند، لذا

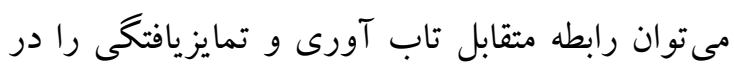

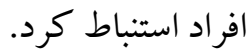
در نهايت، نتايج يزوهش نشان داد كه خود تمايزيافتكى

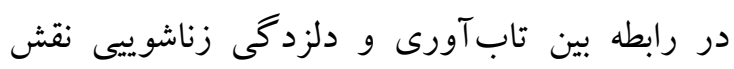
واسطه اى دارد. به اين معنا كه تاب آورى از طريق خود تمايزيافتخى بر دلزدگى زناشويى اثر غير مستقيم

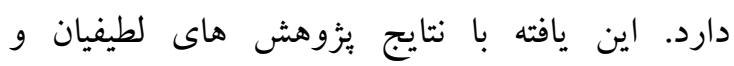
فخارى(Y)

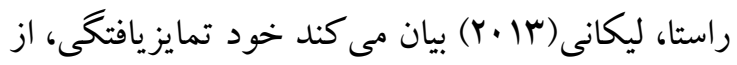
آميختگى زن و شوهر در مواقع بحرانى جلو گيرى

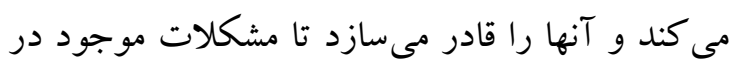
رابطه را با عقل و منطق و نه بر اساس واكنش

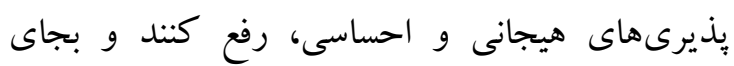
فاصله گيرى عاطفى از يكديخر در موقعيتهاى دشى دشوار، رقئ با تاب آورى در برابر اين مشكلات به سمت زندى إنى

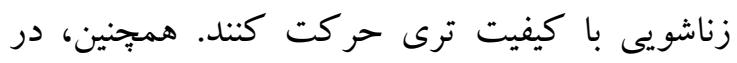
تبيين اين يافته مىتوان كفت افراد با تمايزيافتكى بالا

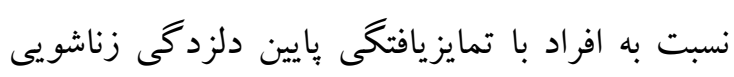
هايينى دارند و همجنين از رضايت زناشويى و كيفيت

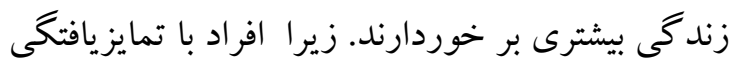

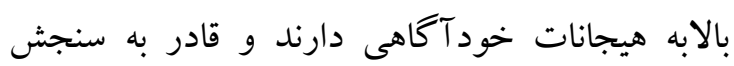
متفكرانه موقعيت هستند. اين افراد توانايى رشد من بـ بـ مستقل را در روابط صميمانه را دارند و مىتوانند در روابط عميق و روابط زناشويى آرامش و راحتى خود را حفظ كنند و از امتزاج و كسلش عاطفى براى تعديل تنشهاى درونى خود اجتناب كنند (ميلر، آندرسون و

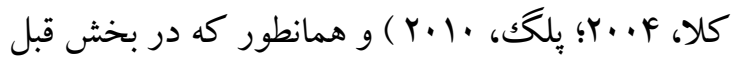
مطرح شد افرادى كه خودتمايزيافتخى بالايى داشته باشند از تاب آورى بالايى نيز برخوردارند و افراد داراى

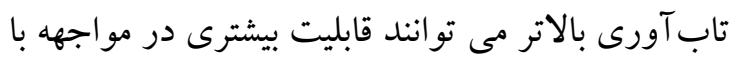

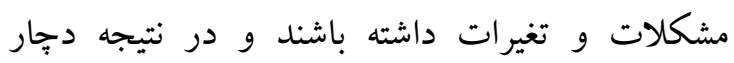


Kim, H., Prouty, A. M., Smith, D. B., \& Wetchler, J. (2015). Differentiation, Resiliency and Healthy Family Functioning of Koreans in the United States, and White Americans. Joumal of Health, 41(1),72-85.

Kline, R. B. (2010). Principles and practice of structural eqution modeling. $3^{\text {rd }}$ edition. New York: Guilford Press.

Knerr, M. R. (2008). Differentiation and power in couple therapy. Unpublished doctoral dissertation: The Ohio State University.

Kochaki, A. ., \& Karbalai, M. A. (2017) The mediators role of rumination of anger and rumination of self-indulgence in the relationship between frustration and marital violence. Joumal of Thought and Behavior, 11(43),92-47. (Farsi)

Kworn, D. O. (2000). The relationship between marital satisfaction, self-esteem and Bowen differentiation of self. Unpublished doctoral dissertation Alliant International University. Los Angeles: Califomia.

Kyung-Sil, K. (2006). Self- differentiation, perceived family conflict and cultural values among Asian American college students. Unpublished doctoral dissertation: Columbia University.

Lahav Y., Stein, JY, Solomon, Z. (2016). keeping a healthy distance: Self-differentiation and perceived health among ex-prisoners-of-war's wives. Joumal of Psychosomatic Research, 89:68-1.

Latifian, M., \& Fakhary, N. (2014). The mediation role of self-differentiation in relation to family communication patterns and mental health. Joumal of Cultural-Educational Women and Families, 8(26):83-65. (Farsi)

Lievaart, M., Huijding, J., VanderVeen, F. M., Hovens, J. E. (2017). The impact of angry rumination on anger-primed cognitive control. Joumal of Behaviour Therapy, 54, 135-42

Likcani, A. (2013). Differentiation and intimate partner violence. Unpublished doctoral dissertation. College of Human Ecology: Kansas State University.

Masten, A. S. (2014). Global perspectives on resilience in children and youth. Child Development Joumal, 85(2), 6-20

Mazzarantani, J. (2011). The divorce survival guide: what toy khow to protect your emotional and finantioal security. Miami: Jules Mazzarantani PLLC.

$$
\text { آكاهى بيشتر براى ازدواج و يا برقرارى روابط اقدام }
$$

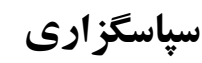

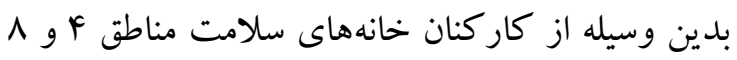

تهران و تمام زنان متاهلى كه در انجام يُّوهش و و

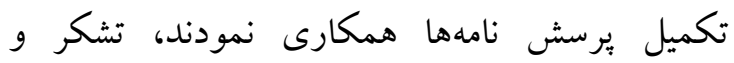

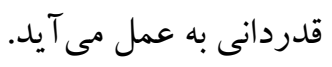

\section{References}

Boldwin, D., Kennedy, D., \& Armata, P. (2008). Short communication with dispositional optimism \& resiliency. Journal of Stress health, 24,393-400.

Chen, Z, Tananka, N., Uji, M., Hiramura, H., \& Shikai, N. (2007). The role of personality in marital adjustment of Japanes couples. Jornal of behivioral and personality, 35(4), 561-572.

Conner, K. M., \&Davidson, R. T. (2003). Development of a new resilience scale: The Conner Davidson Resilience scale (CD-RISC). Journal of Depression and Anxiety, 18, 76-82.

Donnellan, M. B., \& Conger, R. D. (2005). The personality factors and enduring marrige. Journal of Research Personality, 39(1), 206-217.

Goldenberg, H., \& Goldenberg, I. (2012). Family therapy: AN overview. Cengage Learning.

Heshmati, R., Qaradeh, A., Jafari, A., \& Golizadegan, M. (2017). Prediction of marital bumout in couples seeking divorce with knowledge of demographic characteristics, mindfulness, and emotional resilience. Family counseling \& psychotherapy, 1(23), 22-1. (Farsi)

Huber, C. H., Navarro, R. L., Womble, M. W., \& Mume F.L. (2010) Family resilience and midlife marital satisfaction. Joumal of Family Therapy, 18(2), 136-45.

Kaleta, K. (2014). marital satisfaction, differentiation of self and stress perceived by women. Polskie forum psychologiczne, 19(3):; 305-19.

Kerr, M. E. (2004). One family's story: a primer on Bowen theory. Washington, DC: Georgetown FamilyCenter. 
McCarthy, L. A. (2006). Influences of couple conflict type, division of labor, and violated expectation on first time parents' individual and marital wellbeing. Dissertation for the degree of $\mathrm{PhD}$ : University of Florida.

Melvin, K. S., Gross, D., \& Hayat, M. J., \& Campbel, J. C. (2012). Couple functioning and post-traumatic stress symptoms in US Army couples: The role of resilience. Research Nursing Health, 35(2,164-270.

Miller, R. B., Anderson, S., \& keala, D. K. (2004). Is Bowen theory valid? A review of basic research. Joumal of Marital Family Therapy, 30:453-70.

Mohamadi, M. (2010). Investigating the factor affecting swing exposure to people at risk abuse. Unpublished doctoral dissertation. University of social welfare and rehabilitaton sciences, Tehran: Iran. (Persian)

Navidi, F., Adib Rad, N., \& Sabaghian, Z. (2007). Investigating the relationship between marital disturbance and organizational climate factors in male and female nurses. Joumal of Consulting Research, 43(13), 275-87. (Farsi)

Neff, L. A., \& Bradly, E. F. (2011). Stress resilience in early marriage: Can practice make perfect? Joumal of Social Psychology, 98:1-18.

Ong, A., Bergamen, C., Boker, S. (2009). resilience comes of age: defining features in later adulthood. Joumal of Personality and Social Psychology, 77,1778-804.

Peleg, O. (2010). The relation between differentiation of self and marital satisfaction: what can be learned from married people over the course of life?. The American journal of family therapy, 36, 388-401.

Pines, A. M. (2004). Adult attachment styles and their relationship to burnout: a preliminary, cross- cultural investigation work and stress. Joumal of Family therapy,18,66-80.

Pines, A. M., Hammer, B. L., Neal, B. M., \& Icekson, T. (2011). Job Bumout and couples in the sandwiched Generation. Joumal of Social Psychology, 74(4), 361.

Pokorska, J., Farrell, A., \& Pillai, K. (2013). Relationship fading in business to consumer context. European Marketing Academy conference. Istanbul: Turkey.

Schian, p. (2005). investigating the effect of psychopresentation on increasing the differentiation of the individual from the original family in high school girl students in Tehran's 5th district Master's thesis. Tehran: Tarbiat Moalem University.

Shojaei, F., Shojaee, L., Dastjerdi, R., \& Khorshid Zadeh, M. J. (2015). Investigating the predictive role of resiliency and spiritual strength in marital bumout nurses working in Birjand teaching hospitals. Modem Care Joumal, 12(3),129-33. (Farsi)

Skowron, E. A., \& Stanley, K. L. (2009). Differentiation of self and attachment in adulthood: relational comelates of effortful control. Contemporary Family Therapy, 26, 337357.

Skowron, E. A., \& Schmitt, M. L. (2003). The differentiation of self-inventory: Development and initial validation. Journal of Counseling Psychoogyl, 2003, 45(3), 235-76.

Taku, K. (2014). Relationships among perceived psychological growth, resiliency and marital bumout in physicians. Personality and Individual Differences, 59,120-123.

Walsh, F. (2012). Family resilience: A developmental systems framework. European Joumal of Developmental Psychology, 13,313-324. 